\title{
Parents' Involvement in Distance Learning During the Covid-19 Pandemic
}

\author{
Dini Kurnia Sari ${ }^{1, *}$ Rosyidamayani T. Maningtyas ${ }^{1}$ \\ ${ }^{1}$ Department of Primary School and Preschool Education, Faculty of Education, Universitas Negeri Malang \\ *Corresponding author.Email: dinidinkur97@gmail.com
}

\begin{abstract}
The purpose of this research is to determine how parents are involved in distance learning during the Covid-19 pandemic. This research used survey method by distributing research questionnaires using google form. The sampling technique used purposive sampling with the sample criteria being parents who have children aged 3-6 years. The questionnaire was distributed online through application Whatsapp . From 39 parents it was found that $57 \%$ of parents were at the undergraduate level of education. The results showed as many as 25 respondents or $83 \%$ of parents were in the good category in their involvement in accompanying children during distance learning. Based on the results of the study, it can be concluded that the involvement of parents in distance learning during the Covid-19 pandemic was in a good category.
\end{abstract}

Keywords: Parental Involvement, Distance Learning, Covid-19 Pandemi

\section{INTRODUCTION}

Since it was determined that covid-19 was a world pandemic, WHO asked all countries to immediately take steps to prevent the transmission of covid-19. Covid-19 is an infectious disease that was first discovered in Wuhan, China in December 2019. Covid-19 attacks the respiratory tract which causes respiratory infections such as pneumonia, MERS, and SARS. The Indonesian government's efforts in preventing the transmission of Covid 19 through the appeal of President Joko Widodo's policy by implementing Large-Scale Social Restrictions (PSBB), Social Distancing or Physical Distancing which appeal to all Indonesians to work from home, learn from home, and worship from home (Nurhalimah , 2020) .

The Covid-19 pandemic caused upheaval in almost all sectors, such as the economy, social, culture and education around the world, such as the closure of offices, schools, universities, air, land and sea transportation stops and the closure of shopping centers. In the education sector, the Ministry of Education and Culture of the Republic of Indonesia, through a circular issued on March 24, 2020, stated that during the Covid19 emergency period, learning at all levels of education from early childhood education to college was carried out at home or online. Educational activities such as administration, evaluation, admission of new students and other educational activities are also carried out online. This policy was carried out to break the chain of spreading covid-19 (Minister of Education and Culture Circular Letter No.4 of 2020 concerning education policies during the emergency period of the spread of Covid-19, 2020).

Various government efforts in preventing the transmission of covid-19 certainly have a significant impact on all aspects of children's lives. UNICEF applead the government to realize that Covid-19 pandemic has impacts on children's health, welfare, development and future. Children who do not understand about Covid-19 can experience mental disorders because they are depressed and feel excessive fear. Therefore, parents must be sensitive if their children have shown signs of experiencing stress and must take immediate action (UNICEF, 2020).

During the Covid-19 pandemic, children and their parents must be at home continuously. The learning alternative chosen during the COVID-19 emergency is online learning. Online learning has been carried out almost all over the world. Online learning is a distance learning process by utilizing internet-based digital media that is able to support the learning process without physical contact between teachers and students, that can make boredom and stress on children, even parents. Parents must have a way to reduce children's boredom 
while at home. Parents need to pay attention to children's psychosocial needs (Rohayani, 2020).

The implementation of distance learning for the early childhood education level and kindergarten cannot be carried out independently by children without the assistance of parents. Early childhood requires direct involvement of parents as companions and guides to participate in a series of distance learning. Parents are expected to be able to guide children to learn from home and replace the role of teachers at school. Starting from providing learning facilities in the form of internet -based digital media, until learning management at home must be managed by parents. Therefore, the importance of the role and guidance of parents in achieving distance learning goals.

Current conditions in the field indicate that distance learning which is carried out at home with the guidance of parents, encountered several obstacles. Such as the parents' lack of understanding of the material, difficulties in growing interest and motivation to teach the child, limited time to accompany the child to learn because they have to work, lack of patience in teaching children at home, lack of facilities and the difficulty of using gadget and Internet connection services. This raises the saturation and the desire of parents to the institution to immediately conduct face-to-face meetings at school as usual.

The results of research by Lilawati (2020) regarding the role of parents in supporting learning at home during the pandemic state that during distance learning, parents help and guide in the work of assignments given by the teacher and learning facilities at home are not more profitable for students when compared to facilities. learning in school according to some parents. Based on the background and previous research, this research is very important to find out how the parents' involvement in accompanying children by distance learning during the Covid-19 pandemic.

\section{METHOD}

The method used in this research is a survey method, where primary data collection is done by distributing research questionnaires to respondents. The research questionnaire was in the form of questions about parental involvement in distance learning. The sampling technique used purposive sampling with sample criteria are parents who have children aged 3-6 years. The consideration is that at the age of 3-6 years, usually children are at the preschool or kindergarten level who not been able to carry out distance learning independently without parental assistance.

Due to pandemic conditions, a questionnaire was created using Google Form and distributed online via WhatsApp. The distribution of questionnaires was carried out for four days from 9 September 2020 to 12
September 2020 with 39 respondents obtained. The questionnaire instrument in the form of 9 items included the provision of facilities, mentoring time, material understanding, activity management, use of media to the feelings of parents while accompanying children. in distance learning. The assessment of the questionnaire items used a Likert scale, which is often, sometimes, never. Data processing using Microsoft Excel program. The qualifications for the range of values to involve parents in distance learning will be presented in table 1 below.

Table 1. Value Range of Parental Involvement in Distance Learning

\begin{tabular}{|c|c|}
\hline Score & Qualification \\
\hline $\mathbf{9 1 - 1 0 0}$ & Very good \\
\hline $\mathbf{7 5 - 9 0}$ & Well \\
\hline $\mathbf{6 0 - 7 4}$ & Pretty good \\
\hline $\mathbf{4 0 - 5 9}$ & Not good \\
\hline$<40$ & Very Less Good \\
\hline
\end{tabular}

\section{RESULT AND DISCUSSION}

The latest parental education data obtained from the results of filling out the questionnaire is $17 \%$ at the junior high school level or as many as 5 respondents, $47 \%$ at the senior high school or vocation school level or as many as 14 respondents, $57 \%$ at the bachelor level or as many as 17 respondents, and $10 \%$ at the magister level or as many as 3 respondents.

Based on the data, it can be concluded that the parents' education level is at the $\mathrm{S} 1$ higher education level. The percentage of parents' latest education can be seen in Figure 1 below.

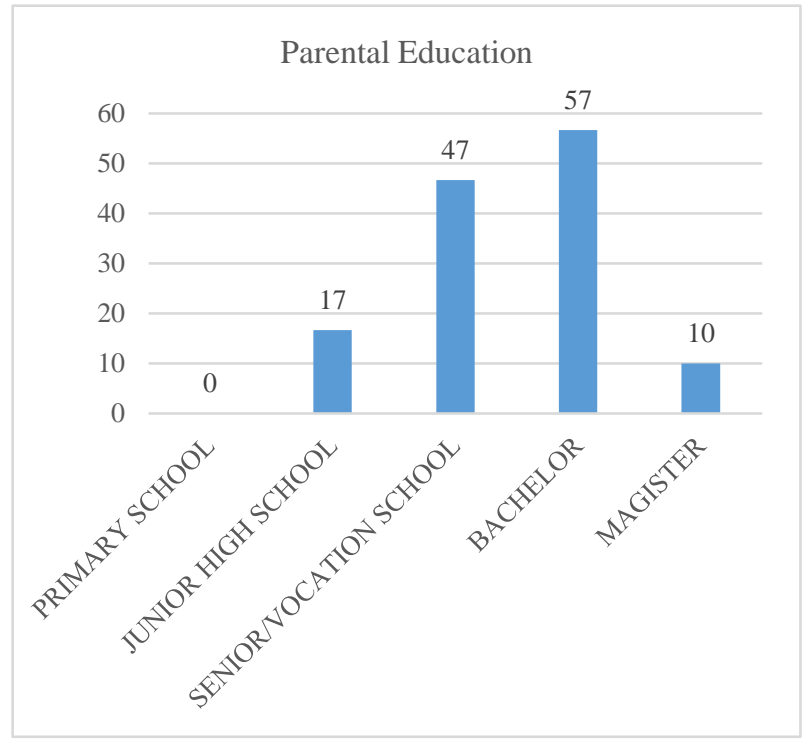

Figure 1 Percentage of Parents' Latest Education.

The level of parental education affects the continuity of children's education. The mindset and educational orientation given to their children will be influenced by the level of education of the parents. 
Table 2. Percentage of Parental Involvement During Distance Learning

\begin{tabular}{|c|l|c|}
\hline No. & \multicolumn{1}{|c|}{ Aspect } & Average (\%) \\
\hline $\mathbf{1}$ & $\begin{array}{l}\text { Provision of facilities and infrastructure in the form of mobile phones and Internet service coverage during } \\
\text { distance learning }\end{array}$ & $\mathbf{1 . 0 1}$ \\
\hline $\mathbf{2}$ & Granting permission to play outside the home during the Covid 19 pandemic & $\mathbf{0 . 8 2}$ \\
\hline $\mathbf{3}$ & Take the time to accompany the child during distance learning & $\mathbf{1 . 0 8}$ \\
\hline $\mathbf{4}$ & Fostering children's interest in learning at home & $\mathbf{1 . 0 4}$ \\
\hline $\mathbf{5}$ & Assistance in carrying out school assignments & $\mathbf{1 . 0 2}$ \\
\hline $\mathbf{6}$ & Understanding of learning material by parents & $\mathbf{1 . 0 4}$ \\
\hline $\mathbf{7}$ & Management of children's play and learning at home & $\mathbf{0 . 9}$ \\
\hline $\mathbf{8}$ & Utilization of various learning media & $\mathbf{0 . 9 7}$ \\
\hline $\mathbf{9}$ & Degree of parent saturation during distance learning & $\mathbf{0 . 8 9}$ \\
\hline
\end{tabular}

The higher the education of parents, the more open parents think about education and how to educate their children (Novrinda et al., 2017). The results of data collection on the parents' involvement in long-distance learning during the Covid 19 pandemic can be seen in table 2. Table 2 shows that the highest average parental involvement is taking the time to accompany children during distance learning.

Meanwhile, the involvement of parents in managing children's play and learning schedules is in the lowest rank, with an average percentage of 0.9 . This means that the management of children's play and learning at home still needs to be improved. Parents must make an agreement with their children about daily hours related to play, study, rest, and other activities during the Covid-19 pandemic, which means that children spend more time at home.

The role of parents during the Covid-19 pandemic in general is to become educators, mentors and supervisors as well as providers of a sense of security and comfort when children are at home. The condition when children gather with family has a higher intensity than just activities at home during the pandemic. Based on the research results, it was found that the percentage of children's play and learning activity management at home only reached $0.9 \%$. This shows that there are limitations for parents in providing play and learning activities to children at home during the pandemic period which can have an impact on the emergence of children's boredom at home. These findings are in line with Gloria's research (2020) which states that activities carried out only at home will cause boredom and make children fussy, so that the readiness of parents is very important in dealing with fussy children, of course starting from the ability of parents to deal with their own boredom.

The qualification data for parental involvement in this study were obtained from the results of filling out a questionnaire on parental involvement with 39 respondents. The frequency distribution of parental involvement data can be seen in table 3 . Based on Table 3 it is known that there are 8 respondents or $27 \%$ are in the very good category, while as many as 25 respondents or $83 \%$ are in the good category, and 5 respondents or $17 \%$ are in the quite good category, $3 \%$ or 1 respondent is included in the unfavorable category, and there were no respondents in the very unfavorable category. The percentage regarding parental involvement in distance learning can be seen in Figure 2.

Table 3. Frequency Distribution of Parents' Involvement in Distance Learning

\begin{tabular}{|c|c|c|c|}
\hline Score & Category & Frequency & Percentage \\
\hline $\mathbf{9 1 - 1 0 0}$ & Very good & 8 & 27 \\
\hline $\mathbf{7 5 - 9 0}$ & Well & 25 & 83 \\
\hline $\mathbf{6 0 - 7 4}$ & Pretty good & 5 & 17 \\
\hline $\mathbf{4 0 - 5 9}$ & Not good & 1 & 3 \\
\hline$<40$ & Very Less Good & 0 & 0 \\
\hline \multicolumn{3}{|c}{} \\
\hline
\end{tabular}

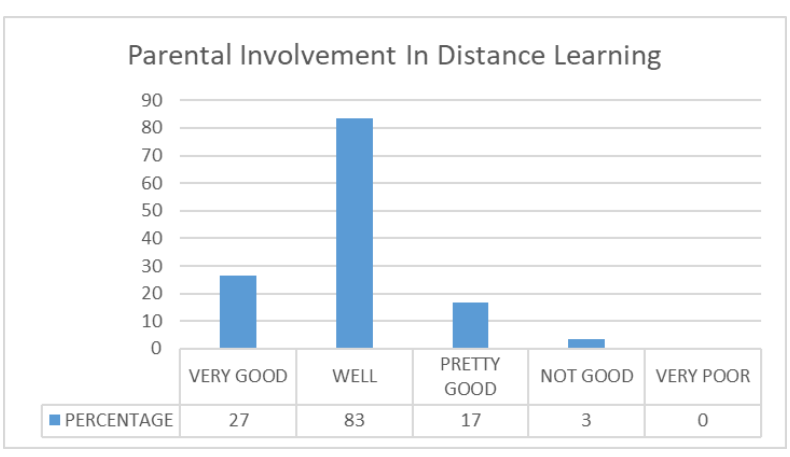

Figure 2 Percentage of Parents' Involvement in Distance Learning.

In Figure 2 it is known that the majority of parental involvement in distance learning is categorized as good. This is known from the acquisition of a higher percentage in the good category, which is $83 \%$. It can be concluded that the involvement of parents in distance learning falls into the good category.

School is a second home for children, where children feel comfortable, fun, full of meaning and warm. At school, children can freely socialize with their friends, teachers, school guards, sellers in the canteen and anyone else in the school environment. However, during the current pandemic, children can only dream of being able to play with their friends and explore new things together at school. Research by Sari et al (2020) states that during the Covid-19 pandemic, children tend to be fussy because they don't go to school and feel missing their friends and teachers.

Based on the results of research on the parents' involvement in distance learning in the aspect of taking 
time to accompany children, getting the highest percentage compared to other aspects is $1.08 \%$. Since the implementation of work from home, parents spend more time with their children. This makes it easy for parents to take the time to assist children in learning and playing. Many parents agree that they are the ones who help their children complete tasks from school. The influence of the role of parents on the application of distance learning during the Covid-19 pandemic is very high. This is in line with Lilawati's research (2020) which states that the influence of parents as a motivator to foster children's motivation and interest in learning is the most visible.

Judging from the latest education data of parents, in general parents are very well educated, namely $57 \%$ at undergraduate level. With the high educational background of parents, the use of gadgets and internet services is not a significant problem. This is in accordance with Sari et al.'s (2020) research regarding the readiness of mothers to play with their children during the Covid-19 pandemic "at home", which states that with a high educational background, internet access and use of gadget are very easy for parents. For them, the internet is a means of finding educational and parenting references as well as a source of reference for designing media or playing activities with children at home.

The results of the research which states that the involvement of parents in distance learning is in the good category also cannot be separated from the level of parental understanding of the learning material. The results of the study on the aspects of parental understanding of the learning material obtained a percentage of 1.04. This shows that the learning material provided by the teacher can be understood and mastered well by parents. So that assistance in the learning process at home can be said to be good. In line with the research of Irma et al (2019) which states that the understanding of material and broad thoughts that parents have is very useful to help the learning process at home. Parents must understand well the learning material from schools, so that the implementation of education at home can be successful (Wardani \& Ayriza, 2020).

\section{CONCLUSION}

Based on the results of the research and analysis that has been conducted, it can be concluded that the involvement of parents in distance learning during the Covid-19 pandemic is categorized as good with a percentage of $83 \%$. The results showed that the level of education of the parents was also categorized as good because $57 \%$ of parents were at the higher education level. This affects the provision of learning facilities such as the use of gadgets and internet services and the understanding of learning materials. During the Covid-19 pandemic, in general parents, Because the application of work from home parents can spend more of their time accompanying children to study or just play. Parents can also foster motivation and interest in children's learning well, but they have enough problems with children's boredom when they are at home continuously which causes children to be fussy.

\section{REFERENCES}

[1] A. Wardani \& Y. Ayriza, “Analisis Kendala Orang Tua dalam Mendampingi Anak Belajar di Rumah Pada Masa Pandemi Covid-19," Jurnal Obsesi: Jurnal Pendidikan Anak Usia Dini, vol. 5, no. 1, pp. 772-782, 2020.

[2] A. Lilawati, "Peran Orang Tua dalam Mendukung Kegiatan Pembelajaran di Rumah pada Masa Pandemi," Jurnal Obsesi: Jurnal Pendidikan Anak Usia Dini, vol. 5. No. 1, pp. 549-558, 2020.

[3] K. Khadijah, "Pola Kerja Sama Guru Dan Orangtua Mengelola Bermain Aud Selama Masa Pandemi Covid-19," Kumara Cendekia, vol. 8, no. 2, pp. 154170.

[4] N. Nurhalimah, "Upaya Bela Negara Melalui Sosial Distancing Dan Lockdown Untuk Mengatasi Wabah Covid-19 (Efforts to Defend the Country Through Social Distancing and Lockdown to Overcome the COVID-19 Plague)," 2020. Available at SSRN 3576405

[5] UNICEF, “COVID-19 dan Anak-anak di Indonesia, Agenda Tindakan untuk Mengatasi Tantangan Sosial Ekonomi", Jakarta: United Nations Children's Fund, 2020.

[6] M. Amini, "Profil keterlibatan orang tua dalam pendidikan anak usia TK," Jurnal Ilmiah Visi, vol 10, no. 1, pp. 9-20, 2015.

[7] N. Novrinda, N. Kurniah \& Y. Yulidesni, Peran "Orangtua Dalam Pendidikan Anak Usia Dini Ditinjau Dari Latar Belakang Pendidikan,” Jurnal Ilmiah Potensia, vol. 2, no. 1, pp. 39-46, 2017.

[8] Gloria, "Sehat Mental Selama di Rumah dengan Aktivitas Positif Bersama Keluarga," Ugm.Ac.Id, 2020.

[9] C. Irma, K. Nisa \& S. Sururiyah, "Keterlibatan Orang Tua dalam Pendidikan Anak Usia Dini Di TK Masyitoh Purworejo," Jurnal Obsesi: Jurnal Pendidikan Anak Usia Dini, 2019. DOI: https://doi.org/10.31004/obsesi.v31i.152 